удк: 930.2:94(477.53):355.48(100):343.343.5

DOI: $10.26661 /$ zhv-2019-1-53-10

\title{
Behavioral Deviations at The First World War (by the materials of Poltava Province)
}

\author{
V. Sarancha \\ Kremenchuk Mykhailo Ostrohradskyi National University \\ visar73@ukr.net

\section{Shabunina} \\ Kremenchuk Mykhailo Ostrohradskyi National University \\ shabuninaviktoria@gmail.com
}

Key words: First World War, Poltava province, espionage-mania, Jews, mobilization, "dry law"
The main forms of widespread behavioural deviations of the population of Ukraine's rear provinces during the First World War are characterized in the article. Particular attention is paid to manifestations of anti-Semitism, Germanophobia and espionage-mania, as well as an effect of the "dry law" on Poltava province people. The ways of evasion from call-up and the region dwellers' attitude to this phenomenon are considered. The analysis of the criminogenic situation in Poltava region during the Great War of 1914-1918 is carried out.

\section{Поведінкові девіації під час Першої світової війни (за матеріалами Полтавської губернії)}

\section{B. I. Саранча \\ Кременчуцький національний університет імені Михайла Остроградського}

\section{В. В. Шабуніна}

Кременчуцький національний університет імені Михайла Остроградського

Ключові слова: Перша світова війна, Полтавська губернія, шпигуноманія, євреї, мобілізація, «сухий закон»
В статті охарактеризовані основні форми поведінкових девіацій, які були розповсюджені серед населення українських тилових губерній під час Першої світової війни. Особливу увагу приділено проявам антисемітизму, германофобії та шпигуноманії, а також впливу дії «сухого закону» на мешканців Полтавської губернії. Розглянуто способи ухилення від призовів до армії та відношення до цього явища населення регіону. Проведено аналіз криміногенної ситуації на Полтавщині в роки Великої війни 1914-1918рр.
Everyday life of Ukraine's rear provinces during the First World War is a poorly researched page of the national history. The study of the phenomena that arose during the Great War of 1914-1918 and their influence on fundamental changes in socio-political, economic and cultural life deserves a special consideration. For a long time development of a provincial socium against a background of global transformations has been out of researchers' sight. In this connection, regional studies on problems of the First World War with the use of modern methodology acquire especial scientific significance.

Since the middle of 1990s the Ukrainian scholars have actively studied issues related to the activities of charitable and other civic organizations, refugees, military captivity, military censorship, etc. during the First World War. For the first time scientific works on the historiography of the Great War and comprehensive regional studies have been appeared; questions of the war influence on mass consciousness and social behaviour of different strata of society have been raised.

Up to the present a monograph of the Russian researcher 0 . Porshneva has been remained the most thorough work highlighting the social problems of the Great War on the basis of modern methodology [1]. On a wide sources base the author has reconstituted the peasants' perception of the war and the evolution of the soldiers' perception of the phenomenon, while expressing her thoughts on the nature of revolutionary violence and anarchy. Unfortunately, in Ukraine such studies have not been carried out until now.

The purpose of this study is to characterize the main forms of destructive behaviour of Poltava province inhabitants during the First World War.

At the end of the 19th century a general increase in the manifestations of deviant behaviour 
among population of the Russian Empire was to be observed; it could be associated with a negative person's reflection on modernization of the socio-cultural environment. Just before the Great War not only the metropolitan press, but also Poltava's newspapers adduced information about suicides of young teachers and secondary-school girls, robberies, brutal killings that had been often occurred on the grounds of mental disorders or alcoholism, etc. During the war the other destructive practices associated with the militarization of social life and active participation of new social groups in it were added to the traditional forms of deviant and delinquent behaviour.

With the beginning of the war due to media propagandistic activities among the population there were spread specific destructions, such as espionage-mania and internal enemy search, which were in essence the veiled forms of xenophobia. Despite the official warnings against spreading xenophobic attitudes of mind towards citizens of the Central states, they appeared on the pages of central and regional editions all the same. Articles with a crushing anti-German critique began to dominate in the informal part of Poltava diocesan gazette ("Poltavskiye yeparkhial'nyye vedomosti") and other editions.

Since the August of 1914, district police departments have been sent data about the conjectural spies and residents who could appear on the territory of Poltava region. During the war a number of outgoing correspondence from district police officers to the MGB (the main gendarmerie board) has significantly increased, who were forced to report about the absence of spies often with exotic names, such as Bulgarians Nazabol and Shuyusuyamudeneg, in Zinkiv or Hadiach [2, s. 48; 22, s. 51; 23, s. 30].

In conditions of socio-psychological tension and Germanophobia, the police received reports of spy activities intensification in the districts of the German population's living. In particular, in the early November of 1914 a peasant of khutor Khreschatyk Syromlia spread information on probable night flights of aeroplanes over Romny district. After the investigation a district police officer considered Syromlia's claims to be unfounded and caused by near living of the German agricultural colony of 60 households, whose members were the Russian subjects [3, s. 6].

At the same time in Kostiantynograd district a German citizen F. Hutiar was arrested; he was accused of giving talks with local peasants, during which he had emphasized their difficult financial position and the impossibility of Russia's victory over Germany [4, s. 8, 9]. At the beginning of the war Poltava's dweller R. Busse was also imprisoned; he fell into police's field of vision as a person without concrete occupation who was interested in the mobilization processes. In arrest's time R. Busse tried to pass a note in German in a bread crumb to an owner of Poltava store Schindler, who was also arrested and sent to Orenburg province [4, s. 10-12, 14-16].

An active phase of the social espionage-mania and the search for an "inner enemy" fell on 19141915 , while gendarmerie's prejudice attitude to the Germans and the Austrians was observed during the war. While searching the illegal union "Good hour" a miller of the Lutheran religion K.-V. Hrinfeld got under police surveillance despite he had been living in Poltava for almost 25 year; he had a wife and three children $[5$, s. 2, 12, 18]. Xenophobic sentiments were recorded in police reports; in particular, the Kostiantynograd police officer noted a great hatred of population of the district to the Germans and Turks $[6, \mathrm{~s}$. 15 see over].

Arrests and deportations of a large number of Central states citizens from Poltava region led to reorientation of the search for an internal enemy and deepened anti-Semitism, a traditional kind of xenophobia in the region. At the same time with the outbreak of the war Jewish entrepreneurs actively expressed their loyal feelings, and Jewish soldiers showed their heroism during hostilities.

In the province inhabitants' mass consciousness Jews were perceived as immutable opponents of the existing system, who concealed resentment during the war demonstrating complete indifference to current events. In this connection the Jewish inhabitants' patriotic feelings were often perceived as manifestations of the social mimicry. However at the beginning of the war unification of citizens of different nationalities against a common threat was fixed in the progressive press and police officers' reports.

In the midst of the anti-German propaganda of 1914-1915 anti-Semitic sentiments were spread within their traditional social environment. Poltava MGB received letters of complaint from the "loyal subjects of His Majesty" about preparation for an attempt of the Jews - "the enemies of the Russian state" - on Nicholas II life in the December of 1914 [7, s. 30, 31, 31 see over], about intimidation of the doctor of recruiting commission by Jewish recruits [7, s. 29], etc.

Since the beginning of the war the Jews have become figures of statements as to spreading rumours of rapid defeat of the Russian army; they have been 
accused of popularizing the German way of life and criticizing the Russian social system. "Jewish trace" - a Jew-witness, agitation in a store belonging to Jew owner, etc. - became an unchanging attribute in matters concerning offence to the emperor, anti-war statements, etc. During the war such words as "defeatists", "evaders", and "apologists of the German orders" were added to the traditional negative connotations in perception of the Jews. Thus, in the struggle against "an internal enemy" a circle of its search was outlined - the Jews and the Germans living on the territory of Poltava province.

It is worth noting that this kind of destructive behaviour was not limited to letters-complaints, defamatory articles in periodicals and general tension of interethnic relations. In the July of 1915 the Poltava Court was submitted a case of a Cossack P. Shchypets and a priest M. Prochaiev; they circulated a proclamation appealing to beat the Germans and the Jews in Khorol [8, s. 47]. With the advent of Jewish refugees in the district and their employment there were spread the threats of pogroms in case of Slavic workers discharge [9, s. 24, 27].

Since the middle of 1915 the rise of a new wave of anti-Semitism has begun. Society firmly convinced of the thought that just the Jews raised prices for essential goods and services and hid gold and silver coins. The main argument for these thoughts was concentration of almost all industry and trade in hands of Jewish entrepreneurs. In that period the police also fixed the revival of Jewish party organizations' activities, the spread of pacifist literature, and so on.

Front-line soldiers' information was also in favour of negative perception of the Jewish. They gave details about increase of espionage, desertion and yielding themselves prisoners among the Jews. In the spring of 1916 such sentiments have become widely spread within the empire, and the Police Department appealed to Poltava Governor R. Molov to take measures to prevent pogroms [10, s. 25].

As a result of the mobilization of 1914-1915 Poltava region have lost a considerable contingent of the most active population that in the vast majority was morally and psychologically ready for military service. On the other hand in first weeks of the war prosperous dwellers tried to evade the call to military service; against the background of growing economic problems it led to an increase in social tension.

At the end of 1915 the majority of reservists of the province besides workers of defence enterprises were the "white ticket" holders and the second-class home guard soldiers, who were released from the actual service for medical or family rea- sons.

During the First World War the evasion from mobilization has become a dominant motive in behaviour of these categories of inhabitants, to whom a significant part of the wealthy urban and rural population irrespective of their denominational affiliation can be added [11, s. 2].

The easiest legal way to avoid mobilizing was getting a job at defence enterprises, in militarized institutions or on railway tracks lines building. Sometimes for being employed a potential mobilized soldier paid the sum which significantly exceeded his future annual earnings. In this way the group of wealthy peasants who had paid bribes of 200-300 roubles fell into the service of Poltava fire brigade [12, s. 56].

At a grenade plant under Poltava in the colony of mental cases worked 320 persons of a staff; 126 of them were the Jews-soldiers who had received deferrals as workers of a defence enterprise. Being watchmakers, clerks and tradesmen by speciality they worked at the factory as locksmiths and tinsmiths. The daily travelling expenses of a Jew-worker of the grenade plant were 3 roubles, and the earnings per shift ranged from 70 kopecks up to 1 rouble 50 kopecks [13, s. 112, 114, 123].

In order to evade mobilization the prosperous people - a former volost starosta Tyhostup and a landlord Postekhin - have got a job in Poltava Ca$\operatorname{det}$ Corps as foremen [14, s. 17], and young teachers of a music school Morozov and Muller have registered their names in the school as pupils [15, s. 30]. During this period there were cases to be registered when entrepreneurs and individuals used the false documents and the sign-boards providing information that their companies worked for defence.

A traditional form of the evasion from mobilization during the war was pronouncing a person unfit for active service on medical indications, which could be obtained on account of mutilation or corruption of the persons who were responsible for call-up. The police reports contained information on home guard soldiers' taking a medicine that caused ulcers on a body or feigned scrofula, etc. [16, s. 178]. V. Bilenkyi fell into police field of vision; by agents' observations he went for clandestine trips to Berdichev together with the Jewish reservists; there those persons were made mutilations for the purpose of their release from mobilization [17, s. 25 see over].

At the same time information about corruption in the district offices of military service came to Poltava MGB. In 1916 the board received information that a head of Lokhvytsia committee of the "white ticket" holders' examination and a district 
police officer had taken bribes for release from the call-up [17, s. 24 see over].

According to gendarmes' informants Lubenskyi district military commander B. Ugnyvenko was assisted by doctors and special agents in the illegal activity of persons' release from military service. A high rate of Lubny district's persons pronouncing unfit for active service, his significant money savings in the local bank and the real estate in Katerynoslav have become as confirmation of $\mathrm{V}$. Ugnyvenko's corruption activities. In addition, observation notes contained the data that in 1916 a district office clerk R. Balva, who have already had a house, began the construction of another one [18, s. 35-40, 64].

Jewish inhabitants' specific way of military service evasion was emigration to the United States. After receiving a deferral from call-up they made their way to Harbin and Shanghai through intermediaries, and there they got the departure documents for a 300 roubles' bribe to a local police head. According to Poltava MGB' data in January of the 1916 only through the mediation of Jew Dardyk 50 persons left for Harbin $[18$, s. 20].

Introducing the state monopoly on a strong drinks sale (1895) led to the spread of everyday hard drinking with all the negative social consequences. At the beginning of the 20th century in most of district towns of Poltava region and in rural areas there were appeared people's sobriety societies and the proper topics were regularly published in regional periodicals. The highest decree on the prohibition of strong alcoholic drinks sale was positively perceived by educated part of society; as regards this they allowed themselves a wary criticism of the government for getting a huge profit out of a common trouble the hard drinking [19].

In the first months of the war there was observed euphoria from simultaneous sobering of provincial life, which has acquired a new economic and spiritual content. According to Zemstvo statisticians a small Poltava's village spent 5-6 thousand roubles for alcoholic drinks a year. In the first three months of the "dry law" the increase in savings and in consumption of tea, sugar and meat was fixed. Cultural and spiritual needs of a village become one of the main topics of the zemstvo and diocesan periodicals. Lack of sufficient information in letters from the front led to the demand for printed editions; the Zemstvos enlarged assortment of reading-halls and libraries, and set up additional literacy courses for adults.

The availability of additional means enabled peasant families to make regular trips to cities, vis- it cinemas, buy musical instruments, gramophones, etc. The prohibition of strong alcoholic drinks sale led to re-profiling some institutions; in return according to the results of 1914 the Kremenchuk Municipal garden got no profits in the new conditions [20].

External euphoria from the "dry law" effect was accompanied by the formation of illegal alcohol market, the spread of home-brewing and the use of surrogates. A response to deepening of these negative tendencies was the compulsory regulation of Poltava's governor concerning the police permission necessity to buy or sell wood alcohol, methylated spirits, colognes and polishes from which the surrogate alcoholic drink "Hanzha" was produced [21].

In his letter dated the 12th of January, 1915 to the head of the MGB a governor 0. Baggovut expressed concern about increase in the number of cases of the hard drinking among lower ranks, officers and military officials. In view of this the gendarmerie department was ordered to strengthen control over the illegal alcohol market, home-brewing and selling of "Hanzha" [22, s. 13-16].

The black market of quality alcohol existed primarily in big cities of the province to meet demand of the elite groups of society, such as officers, commercial and industrial bourgeoisie, creative intellectuals, etc. Having been bought in Moscow, Kharkiv or other large cities the strong drinks were sold to the wealthy customers who ordered hotel rooms to drink the liquor there.

Holidays brought especially large receipts. In particular in 1916 in Poltava a hotel has got 1,000 roubles' profit out of the alcoholic drinks selling during the New Year's holidays. Champagne was of great demand among officers of the garrisons; in 1916 a bottle of champagne cost 15 roubles at illegal markets. In the same period Poltava MGB received information that a son of the owner of Poltava Grand Hotel organized liquor deliveries to the Army in the Field $[23$, s. 20, 21, 58].

At that time in a country-side there were spread home-brewing and purification of the methylated spirit intended for the use in a spirit cooking-range. In towns of the province the lowest rank servicemen of local garrisons were the main clients of the traders of non-purified methylated spirit and "Hanzha". The sale of surrogate alcohol was often carried out in booths for the sale of kvass and fruit drinks, by which methylated spirit and polishes were painted. A bottle of methylated spirit diluted with a juice of pears or cherries cost 2 roubles, whereas the poor could buy a wine-glass of this drink for 15 kopecks $[24$, s.60]. 
Illegal sale of alcohol was especially profitable in the places where troop trains were bound for the front, so this way of earnings was widespread in the shops near railway stations. Trade in alcoholic substitutes have been often carried out with participation or patronage of the individuals who would have to fight against this phenomenon. In particular in 1916 Poltava MGB received information that a deacon of the village Zhuky $[24,5.69,147]$ and a wife of Lubny cavalry sergeant major Andreev [25, s.109] have traded in purified methylated spirit.

In the same period a police-officer Koselevskyi have issued a permit for the purchase of methylated spirit to his concubine Drobysheva, who sold it to servicemen. It should be added that Drobysheva as well as the most of illegal traders had been informed in advance about the planned raid inspections; in many gendarmes' reports there were notices about that $[26$, s. 135]. At the same time profiteers and secret alcohol traders tried to strengthen their own position by slandering the police officers who had refused to protect them [26, s. 85-87].

During the war in Poltava and Kremenchuk there was a chain of the gambling dens as well as the haunts where prostitutes were kept and surrogate alcohol was sold. The main visitors of these institutions were lower rank servicemen of garrisons and even prisoners of the war. In most cases in 1916 the disclosure of illegal trading institutions was accompanied by arresting prostitutes. Women owning dens have often kept house together with soldiers. In order to avoid arrests by the patrol during the visit of dens, servicemen bought civilian clothes for the money having been got from the sale of military form and property [26, s. 9, 22, 38, 59, 131].

An active buying and selling of military uniforms, accoutrements, horse harnessry, etc. was another characteristic feature of everyday life of the First World War period. Intensive sales of breech things were carried out by soldiers of the largest garrisons of Poltava region. Mass thefts from the Poltava base were committed during the things transportation. Besides that, lower ranks servicemen carried the things out of a warehouse put on them, sometimes holding their old boots in their hands [26, s. 75]. At the same time the police exposed the facts when a person stole material values at railway stations by means of the forged certificate from the factory working for defence [27, s. 54].

Lower ranks servicemen of Kremenchuk garrison tore soles off their boots and sold them to the artillery soldiers who resold them to buyers-up and individuals. Army boots, shirts and sharovary were a bargain for civilian population in conditions of sig- nificant rise in the cost of clothes and shoes [28, s. 77, 114 see over].

Because of lack of quartering military contingent the peasants went to the nearest railway stations where they bought up greatcoats, drawers, canvas, children's clothes sewn from soldiers' capes as well as mess-tins, mugs, etc. at the detachments being removed to a new place of troops' distribution. Soldiers have often been given methylated spirit or "Hanzha" instead of money in exchange of things and clothes. The lower ranks soldiers serving near the house brought stolen goods home during their unwarranted absence and the family members sold them at the market [29, s. 107, 108; 18, s. 55].

Stolen goods, silver and gold coins have often been bought up by stores' holders. For example, at the search in 0 . Perederii's Poltava grocery store one have found 481 roubles and 75 kopecks in coins and a large number of soldier trousers, shirts, sacks, etc. [30, s. 6]. The demand for non-ferrous metals was significantly lower but at the inspection in a private lodging the police confiscated the lead bullets and the cartridge-cases having been purchased from the soldiers [31, s. 81].

About half of the crimes having been committed in Poltava region in the pre-war period were related to violation of property rights. Besides that, the cases of robbery of the church attended by sexton's murder in Lokhvytskyi district and crooks' actions regarding the sale of non-existent land to the peasants in Pereiaslav district were fixed in the police reports. In the summer of 1913 a brutal mass murder took place in the village of Kapustyntsi in Pyriatyn district; 80 girls having been hired by a local tenant in Kyiv region were lost in a burning shed. The local residents who had not been hired because of the high wage demands have committed this inhuman act.

During the war mainly in big cities of the province the deterioration of criminal situation was pointed out. Complication of the economic situation and criminals' arrival from the front-line area to Poltava told on it greatly. Thus, during 1915 the number of small thefts and robberies have been almost doubled in Kremenchuk; abandoning 6-8 children per month at somebody's door, alcohol trading and sale of military things have become the everyday occurrence [32, s. 38-82 see over].

At that time thieves-recidivists from Berdychev, Odessa and other cities arrived in Kremenchuk; the local police investigated the facts of mutilation of people evading from mobilization, and the activities of the group of counterfeiters were stopped. On the fact of the murder of a peasant $P$. Doroshenko Kremenchuk police's operation group with an offi- 
cial dog have gone to Zolotonosha district, where a local resident M. Skakun was arrested on suspicion of committing the crime [32, s. 38-82 see over].

A resonance murder happened on the 11th of May, 1916 in the town Helmiazov of Zolotonosha district. The 71-year-old pious of the fifth region of Zolotonosha district M. Bogatskyi, his wife, his daughter and the maid became victims of the attackers. Father Mykhailo has been serving as a pious for 45 years. He had eight children. We have no information on the motives and the disclosure of this crime [33].

There was the similar criminal situation in the provincial centre. In 1916 the gendarmery fixed the results of inspections as for illegal alcohol trading, selling-up military things, prostitution, concealing deserters. It should be added that sometimes the searches at suspicious persons yielded no positive results; the police was suggested the idea about slanders because of revenge or criminals' skilful conspiracy [34, s. 113, 123, 128].

Thus, the participation of the Russian Empire in the First World War has become a severe ordeal for the population of Poltava province. Despite euphoria in the public life in the July-December of 1914 the weight of wartime, information about failures and defeats as well as numerous victims had oppressive influence on the society and caused mass fears and mania. Aggravation and spreading of the destructive forms of behaviour not only among specific categories (soldiers, refugees, prisoners of war) but also among usual provincial people was a reaction to the new socio-psychological conditions.

Crisis phenomena in provincial society's socio-economic life during the war have complicated the processes of social adaptation, primary and secondary socialization, which led to desocialization, deviant and delinquent behaviour, depreciation of the former values systems, loss of the moral references and features of the national nature. Social marginalization of the population in towns of Poltava province especially in places of compact distribution of a large number of servicemen because of specificity of their social behaviour has become a corollary of the processes.

\section{References}

1. Porshneva 0. S. Krest'yane, rabochiye i soldaty Rossii nakanune i v gody Pervoy mirovoy voyny / 0. S. Porshneva. - M. : ROSSPEN, 2004. - $368 \mathrm{~s}$.

2. The State Archives of Poltava region, f. 83, reg. 1, file 133.

3. The State Archives of Poltava region, f. 83, reg. 1, file 140.

4. The State Archives of Poltava region, f. 138, reg. 1, file 546.

5. The Central State Historical Archive, Kyiv, f. 321, reg. 1, file 220.

6. The State Archives of Poltava region, f. 83, reg. 1, file 144.

7. The State Archives of Poltava region, f. 138, reg. 1, file 546.

8. The State Archives of Poltava region, f. 138, reg. 1, file 559.

9. The State Archives of Poltava region, f. 83, reg. 1, file 145.

10. The Central State Historical Archive, Kyiv, f. 321, reg. 1, file 217.

11. The State Archives of Poltava region, f. 83, reg. 1, file 147.

12. The Central State Historical Archive, Kyiv, f. 321, reg. 1, file 224.

13. The Central State Historical Archive, Kyiv, f. 321, reg. 1, file 220.

14. The Central State Historical Archive, Kyiv, f. 321, reg. 1, file 224.

15. The Central State Historical Archive, Kyiv, f. 321, reg. 1, file 220.

16. The Central State Historical Archive, Kyiv, f. 321, reg. 1, file 224.

17. The State Archives of Poltava region, f. 83, reg. 1, file 146.

18. The Central State Historical Archive, Kyiv, f. 321, reg. 1, file 220.

19. Hutorianyn. - Poltava. - №1, 1915.

20. Pridneprovskiy golos. - Kremenchug. - № 737, 1914; № 824, 1915.

21. Pridneprovskiy golos. - Kremenchug. - №33, 1914.

22. The Central State Historical Archive, Kyiv, f. 321, reg. 1, file 224.

23. The Central State Historical Archive, Kyiv, f. 321, reg. 1, file 220.

24. The Central State Historical Archive, Kyiv, f. 321, reg. 1, file 224.

25. The Central State Historical Archive, Kyiv, f. 321, reg. 1, file 220.

26. The Central State Historical Archive, Kyiv, f. 321, reg. 1, file 224.

27. The Central State Historical Archive, Kyiv, f. 321, reg. 1, file 220.

28. The State Archives of Poltava region, f. 990, reg. 1, file 2.

29. The Central State Historical Archive, Kyiv, f. 321, reg. 1, file 220.

30. The Central State Historical Archive, Kyiv, f. 321, reg. 1, file 224.

31. The Central State Historical Archive, Kyiv, f. 321, reg. 1, file 220.

32. The State Archives of Poltava region, f. 138, reg. 1, file 560.

33. Poltavskiye yeparkhial'nyye vedomosti. - Poltava. - № 16, 1916.

34. The Central State Historical Archive, Kyiv, f. 321, reg. 1, file 224. 